\title{
Assimilert, hybrid eller inkorporert i det etniske? \\ Tilpasning og identifikasjon blant somaliere i Norge
}

Sosiologisk tidsskrift 2006; 14(1):4-33

Katrine Fangen, Universitetet i Oslo katrine.fangen@sosgeo.uio.no

Department of Sociology \& Human Geography University of Oslo

P. O. Box 1096 Blindern

N-0317 OSLO Norway

Telephone: $\quad+4722855257$

Fax: $\quad+4722855253$

Internet: http://www.iss.uio.no/ 


\section{ASSIMILERT, HYBRID ELLER INKORPORERT I DET ETNISKE? TILPASNING OG IDENTIFIKASJON BLANT SOMALIERE I NORGE'}

Katrine Fangen

katrine.fangen@sosiologi.uio.no

\section{Assimilated, hybrid or ethnically incorporated? Adaptation and identification among Somalis in Norway}

This article analyses modes of adaptation and identification among Somalis in Norway. Do Somalis emphasize their belonging to Norwegian or Somali culture or to both? Do they emphasize other cultural belonging as an alternative to the Norwegian/Somali dichotomy? How do different modes of adaptation influence the different variants of identification and belonging?

The article is based on semi-structured in-depth interviews with 37 Somalis. In addition, I conducted participant observation in families and at cultural events, participated in a casual conversation group of young Somalis and regularly participated in a focus group for Somali women. The interviews were conducted in the respondents' homes, in cafes or in my office, depending on respondent preference. The data were collected in the period 2003 to 2005 and all interviews lasted between 1 and 2 hours.

The article shows that Somalis who seek assimilation in Norwegian society tend to underline their Norwegian belonging more, whereas those underlining a hybrid mode of adaptation underline different combinations of Somali and Norwegian belonging. Some who seek to maintain their Somali belonging do not necessarily seek membership in the Somali community in Norway, but instead try to maintain a Somali identity by only partly changing their lifestyle. Ethnic incorporation other than Somali is also a possible alternative, for example underlining one's belonging to an African or Muslim community. Some experience their identity as something they cannot choose, because skin-colour renders Somali belonging the dominant one no matter how integrated one is. Some identities are politicized, because they provide grounds for action and collective organization. Even though ethnicity is an important unit of identification for Somalis, it varies to the extent the individual underlines his or her identity with all Somalis, or with some category of Somalis (for example those with further education) or whether they also underline their identity with Norwegian society.

Keywords: Somalis, integration, identification 


\section{Innledning}

Somaliere har de senere år vært en stigmatisert befolkningsgruppe i den norske offentligheten. Media har hatt et svært ensidig negativt fokus på somaliere helt siden midten av 1990-tallet (jf. Klepp 2002). Men medias fokus gjenspeiler de fordommer som uttrykkes i andre deler av samfunnet, blant politikere, offentlig ansatte og i den allmenne befolkning. Somaliere har på mange måter blitt fremstilt som "de som er vanskeligst å integrere" (Klepp 2002, Engebrigtsen 2004). Statistikken bidrar også i så måte gjennom at somaliere kommer dårligere ut enn de fleste andre innvandrergrupper på de ulike indikatorer for levestandard (jf. Lie 2004). Denne statistikken må ses i lys av at ca. $55 \%$ av somaliere i Norge har kommet i løpet av de siste fem årene (SSB 2005).

Men selv om over halvparten er nyankomne, er det også mange somaliere som har lang botid i Norge. Det var i 1988 at de første større antall av somaliere kom, etter diktatoren Siyad Barres bombing av Hargeisa og Burao. Disse somalierne som emigrerte helt i begynnelsen av borgerkrigen, var blant de mer ressurssterke fra befolkningen (Gundel 2002). De som var barn da de ankom, har gått mange år i norsk skole, og noen er i gang med høgskole- og universitetsutdanning. Også enkelte somaliere som var voksne da de kom, har tatt sin utdanning i Norge. De nyankomne på den annen side, kan søke en slik høy grad av integrasjon, men da har de en lang vei å gå. Alternativt kan de holde seg til allerede etablerte somaliske miljøer og livnære seg på ulike stønadsordninger. Men som eksemplene i denne artikkelen vil vise, er det heller ikke alltid snakk om noe enkelt valg mellom integrasjon eller segregasjon.

I denne artikkelen skal jeg analysere de enkeltes tilpasning til det norske samfunn og se denne i sammenheng med hvordan de betoner sin identitet ulikt: vektlegger de sin tilhørighet til det norske, til det somaliske, eller en blanding av disse? Betoner de andre etniske tilhørigheter som alternativer til dikotomien norsk/somalisk? Hvilke ulike tilpasningsformer (assimilering, hybridisering, etnisk inkorporering) ser ut til å fremme de ulike identifiseringsvariantene?

\section{Metode og metodiske overveielser}

Jeg har utført halvstrukturerte dybdeintervjuer med 37 somaliere: 6 sosialklienter ( 3 menn og 3 kvinner i 20- 30- og 40-årene), 7 kvinnelige studenter i 20årene, 3 mannlige studenter i 20- og 30-årene, 1 mannlig ufaglært arbeider i 20-årene, 1 kvinnelig frisørlærling i 20-årene, 3 mannlige sosialarbeidere i 30og 50-årene, 2 kvinnelige sykepleiere i 40-årene, 6 kvinnelige hjelpere uten formell utdanning i 30- og 40-årene, 1 mannlig lege, som jobbet med integrering av flyktninger, i 40-årene, 1 kvinne som jobbet med integrering av flykt- 
ninger, i 40-årene, og 5 skolebarn (2 gutter, 3 jenter). Ni av intervjuene er gjennomført av min vitenskapelige assistent, Cecilie Thun.

I gjengivelsen av informantenes uttalelser har jeg i en viss grad redigert språk slik at det blir mer grammatikalsk korrekt, men jeg har ikke byttet ut informantenes ord med andre. Alle intervjuene bortsett fra to ble utført på norsk. I disse to brukte jeg tolk. I tillegg har jeg gjennomført deltagende observasjon i familier og ved kulturelle arrangementer, samt deltatt i et par samtalegrupper for unge somaliere og i et par fokusgrupper for somaliske kvinner (med møter fordelt over ett år). Jeg har fått formidlet kontakter fra fem forskjellige nøkkelinformanter, og har da eksplisitt spurt etter ulike kategorier somaliere mht. jobb og utdanning, grad av religiøsitet osv. for å få en spredning i materialet. Intervjuene har blitt gjennomført i informantenes hjem, på kafeer eller på mitt kontor, avhengig av hva informanten foretrakk.

Jeg har spurt om informantenes situasjon i Norge i dag og i perioden fra de ankom. Så har jeg stilt oppfølgingsspørsmål om erfaringer med ulike deler av det norske samfunnet, så vel som om relasjoner til andre somaliere i Norge og til nordmenn, og identifiseringer i forhold til de ulike gruppene. Alle intervjuene varte i 1 til 2 timer. Data ble samlet inn i perioden 2003-2005.

Det er vanlig blant somaliere å definere seg i motsetning til det negative offentlige bildet av somaliere. Når jeg som hvit middelklassekvinne intervjuer somaliske flyktninger i Norge, vil deres behov for å ta avstand fra de somalierne som bidrar til stigmaet aktiviseres. Men somalieres distansering i relasjon til bestemte kategorier av andre somaliere blir aktivert også i somaliske sammenhenger. I somaliske velferds- og interesseorganisasjoner pågår mye diskusjon om behovet for å gjøre noe med den omfattende bruken av khat blant somaliske menn, om arbeid mot kvinnelig omskjæring, samt arbeidet med å motivere somaliere til å ta utdanning og få seg jobb. Også blant somaliere som ikke arbeider aktivt med somalieres velferd, har jeg opplevd at de temaene jeg behandler i intervjuer, er temaer somaliere selv engasjeres av, uavhengig av at jeg introduserer temaene for dem. For eksempel har jeg flere ganger erfart når jeg kjører drosje med somalisk drosjesjåfør, at de tar opp temaet at de som var av de første som kom til Norge, er mer arbeidsvillige enn de som kommer senere. Og somaliske kvinner tar opp temaet om somaliske menn som bruker for mye tid og penger på khat og ikke tar ansvar for familien. Det jeg imidlertid ser at jeg kan aktivere, som hvit kvinnelig forsker, er somalieres frustrasjon og sinne over Norge og nordmenn. Noen ganger har jeg opplevd somaliske kvinner som sint blåser ut sin frustrasjon over hvordan det norske samfunn ikke godtar at de, som syvbarnsmamma, vil være hjemme å ta seg av barn, istedenfor å jobbe, eller sin frustrasjon over at den norske stat blander seg inn i deres familieliv og oppdragelse gjennom barnevern, ppt-tjeneste osv. Fordi jeg er 
norsk, aktiveres deres sinne over det norske i møte med meg. Jeg har prøvd å poengtere at jeg ønsker å formidle deres syn, og at jeg forstår deres frustrasjon, men noen ganger har ikke den andre vært så opptatt av å høre hva jeg sier, men snarere brukt meg som kanal for frustrasjoner. Slike reaksjoner har jeg imidlertid oftere møtt på konferanser der jeg har presentert materialet mitt, enn i selve intervjusituasjonene. Intervjuene har åpnet opp for en dialogsituasjon, hvor jeg tror den andre har følt seg ivaretatt og sett, og det har vært tydelig at jeg vil høre hva de forteller, mer enn å fortelle dem hvordan de er.

\section{Identifikasjon og tilpasningsmåter}

Identifisering kan ses som en stadig pågående forhandlingsprosess, som påvirkes av mediebilder og positive eller negative erfaringer på skolen, i familien, blant venner og på jobben. For flyktninger som synes det er vanskelig å finne seg til rette i et nytt samfunn, kan denne prosessen settes desto mer på spissen. De må tilpasse sin identitet til de endrede livsbetingelsene. Således kan identifikasjonsprosesser foregå hånd i hånd med integrasjonsprosessen inn i det nye samfunnet. Noen vil søke å bevare sin opprinnelige etniske identitet og ønsker heller aldri fullstendig integrasjon, andre søker å assimilere seg og deres etniske identitet endres tilsvarende i retning av det norske. ${ }^{2}$

Disse forskjellene i en etnisk minoritetsgruppes tilpasning til storsamfunnet er godt beskrevet av Harald Eidheim (1987) i hans studie av norske samer. Han skiller mellom en assimileringsstrategi og etnisk inkorporering. Med begrepet strategi betoner han her individet som aktivt velgende og handlende, i tråd med Barths tidlige perspektiv, som beskrevet i Ethnic groups and Boundaries (Barth 1969). Senere har Barth modifisert hvor bevisst kalkulerende individer er i betoningen av sin etnisitet. Jeg slutter meg til en slik modifisering. Det er ikke nødvendigvis slik at minoritetsmedlemmer aktivt velger assimilering eller segregering (som Eidheim kaller etnisk inkorporering), de ulike tilpasningsmåtene kan snarere by seg frem som de eneste mulige alternativene for ulike individer. En innvandrer som enten allerede har utdanning, eller kommer fra et hjem der man er vant til å være aktivt deltagende i samfunnet, vil se det som naturlig å søke en aktiv deltagelse i sitt nye hjemland også, mens de mindre ressurssterke innvandrerne vil kunne oppleve at de har få muligheter for inkludering i sitt nye bostedsland, eller at det nye landet bygger på et helt annet verdisyn enn deres eget, slik at de vil være redd for å miste sin egen identitet ved å søke for mye tilslutning. Det kan altså være et samspill mellom hva man (bevisst) ønsker å oppnå, og hva man føler man uunngåelig blir plassert inn i. Kanskje vil det være slik at de som ønsker assimilering, er mer bevisst strategiske enn de som søker trygghet hos egen etnisk gruppe. Assimilering krever en aktiv, målrettet innsats av innvandrere som kommer fra en kultur som er svært 
annerledes eller et samfunn med en helt ulik organiseringsform (eller snarere mangel på sådan, som i dagens Sør-Somalia).

For å unngå en ureflektert antydning om at alle er like strategiske, har jeg valgt å gå bort fra begrepet strategi, men likevel for øvrig forholde meg til Eidheims analytiske skille mellom assimilering og etnisk inkorporering. I tillegg vil jeg legge til en tredje tilpasningsmåte, nemlig hybridisering, i analysen av identifisering og integrering blant somaliere i Norge. Assimilering og etnisk inkorporering har å gjøre med ulike identitetshåndteringer basert på motstridende forpliktelser. Dette analytiske skillet er velegnet fordi det viser forbindelsen mellom hvordan den enkelte tilpasser seg til samfunnet og hvordan han eller hun identifiserer seg i forhold til ulike etniske og nasjonale kategorier.

Ulik erfaringsbakgrunn fra Somalia påvirker hvordan somaliere opplever møtet med Norge. Tidligere identiteter i forhold til religion, klasse, klan, by/ bygd, sør/nord og utdanning spiller inn i forhold til hvordan de tilpasser seg i Norge. Måten den enkelte blir møtt på spiller også inn. Ulike identitetstilskrivelser fra andre somaliere og fra det norske samfunnet kan skape frustrasjon eller kan tilsvare den enkeltes egendefinisjoner. Noen ganger fører andres definisjoner til konflikter for den enkeltes identitetshåndtering. For eksempel kan en somalisk jente fra sine foreldre, og fra andre voksne i det somaliske miljøet, oppleve et sterkt press til å bruke hijab, mens hun blant vennene på skolen inspireres til en moderne klesstil, og kanskje får negative kommentarer om hun bruker hijaben. Mellom disse motstridende påvirkningene må hun foreta sitt eget valg, men kan så oppleve at valget ikke blir akseptert av den ene eller andre part. Enkelte velger å svitsje inn og ut av identiteter, ved å imøtekomme foreldres krav hjemme, men ta av seg hijaben når de er alene med vennene. Det er fullt mulig å inneha overlappende og samtidige former for etniske identiteter, i likhet med andre former for identiteter, slik at det ikke nødvendigvis er slik at den ene av disse (muslimsk vs moderne og sekularisert) er falsk.

Betoningen av hvordan identitet forhandles eller konstrueres ulikt på ulike arenaer, er i tråd med det situasjonistiske eller sosialkonstruktivistiske perspektivet på etnisk identitet, som i antropologien ikke minst har blitt formulert av Fredrik Barth (1969) som en motvekt til det strukturfunksjonalistiske perspektivet. I sosiologien er dette perspektivet i tråd med Erving Goffmans (1969) tankegang. Goffman bruker begrepet interaction order om det området der selvbildet møter det offentlige bildet. Selvbildet er hvordan vi ser oss selv, eller den måten vi gjerne vil bli sett på av andre. I Goffmans perspektiv har identitet å gjøre med framførelse, og det er ingen nødvendig konsistens i selvet, men snarere delaspekter som vil komme til syne ulikt avhengig av situasjonen.

Mens dette perspektivet i hovedsak er homologt med Barths teori (jf. Jenkins 1987: 59), tilfører Barth (1969) i tillegg betydningen av etnisitet. Han 
vektlegger at etnisk identitet genereres, bekreftes og omformes i samhandling og transaksjon mellom beslutningstagende, strategiske individer (som nevnt har han i senere arbeider gått mer bort fra betoningen av det strategiske). Etnisitet er ikke fiksert en gang for alle, den er situasjonsavhengig. I tråd med dette perspektivet fremheves at kultur er i endring, istedenfor en reifisert enhet som står som en ramme 'over' hverdagslivet. Det vi altså må studere, er de praksiser og prosesser der etnisitet konstrueres, og utgangspunktet for dette er at etniske grupper er gjenstand for identitetstilskrivelse (fra andre) og identifisering fra aktørene selv. Utgangspunktet for analysen er hvordan aktørene selv definerer situasjonen (mer enn hvordan situasjonen faktisk er). Fokus blir på opprettholdelsen av etniske grenser, samt den strukturerte samhandlingen mellom 'oss' og 'dem' som finner sted på tvers av grensene.

Etnisk identitet kan knyttes til hudfarge, religion, språk, klesdrakt eller tradisjon. Jeg operasjonaliserer begrepet etnisk identifisering med empirisk nærliggende begreper som 'jeg føler meg som' (selvbeskrivelser), 'andre definerer meg/min gruppe som' (andres beskrivelser) og oss/dem dikotomier (sosiale grenser) (jf. Østberg 2003:73). Den enkeltes etniske og sosiale identitet blir således et resultat av utfallet av en prosess mellom ekstern (andres) og intern (egen) definering (jf. Jenkins 1997: 55).

Etnisk identitet er en av mange identiteter et individ kan ha. Den måten hvert individ definerer seg på i etniske termer er nært knyttet til hvordan de definerer seg ut fra kjønnsforskjeller, klasseforskjeller og andre strukturerende forskjeller i samfunnet. I tillegg til etnisitet på ulike nivåer, brukes slike strukturerende forskjeller som diskursive temaer for å definere identitet gjennom hvilke deler av befolkningen man føler seg lik og hvilke man ser seg som forskjellig fra (distansering).

Slike kontraster er viktige for all identifikasjon (jf. Eriksen 2003:139). Identiteter er, som Stuart Hall (1996) påpeker, konstruert gjennom forskjeller, gjennom relasjon til den andre, relasjon til hva man ikke er. Som Barth (1969:14) påpeker: Noen kulturelle mønstre brukes av aktørene som signaler eller tegn på forskjeller. I denne artikkelen skal jeg vise hvordan slike kulturelle mønstre også brukes av somaliere i deres identifisering med og distansering fra hverandre. Beverley Skeggs (1997) skriver om ikkeidentifisering som gjenspeiler unge jenters kunnskap om de negative stereotypiene som tilskrives arbeiderklassen. For å distansere seg fra slike assosiasjoner, definerer de arbeiderklassen ut fra karakteristikker som ikke kan brukes om dem selv, slik som det å være fattig, være røff osv. På samme måte definerer mine somaliske informanter seg på mange måter i kontrast med ulike livsstiler, tilpasningsmåter og atferdsformer som ofte assosieres med somaliere i den norske offentlighet.

Istedenfor ikkeidentifisering velger jeg å bruke begrepet distansering. Slik 
distansering kan komme som en reaksjon på negativ attribuering fra andre, eller fra personens følelse av at andre tilskriver ham eller hans gruppe negative egenskaper. Identifisering og distansering er således to sider av samme prosess. $\AA$ A definere hvem man er, handler like mye om å definere hvem man ikke er. Selve det å definere sin identitet via kontraster kan ta form av dikotomisering (Eriksen 1995:434), som vil si etableringen av en bestemt identitet gjennom kontraster vis a vis den andre (Østberg, 2003:86).

\section{Identifiseringer og tilpasningsmåter blant somaliere i Norge}

I dagens Sør-Somalia er trygghet overordnet mer selvrealiserende behov, i og med at landet er uten en sentral styring og menn med våpen i stor grad er de som har makten (på tross av tallrike forsøk på å stable en regjering på benene). Somalia er et land i ruiner; $70 \%$ av befolkningen lever under fattigdomsnivået (Hassan 2004) og internasjonal støtte har i stor grad stoppet opp etter at Operation Restore Hope ble avviklet i 1995. Hele 18 år etter at borgerkrigen startet er Sør-Somalia fortsatt et sted hvor overlevelse er en fulltids sysselsetting. I Norge derimot er det fred og sosiale støtteordninger innebæerer at alle har en stabil inntektskilde selv når de er arbeidsledige og/eller har stor forsørgelsesbyrde. Andre saker blir derfor viktigere enn overlevelse, slik som det å finne seg til rette i et nytt land. For noen vil det å være i trygghet være det overordnede, og sosiale stønadsordninger gjør behovet for å komme i arbeid mindre prekært. Andre ønsker en aktiv deltagelse i samfunnet, og jobber aktivt og målbevisst i retning av å kunne oppnå det.

\section{Assimilering og norsk tilhørighet}

Eidheim (1987) beskriver assimilering som en prosess der den enkelte same inntar en norsk identitet. For somaliere vil en slik total assimilering virke uoppnåelig på grunn av hudfargens sosiale betydning, og dominansrelasjoner mellom den hvite majoriteten og svarte minoritetsmedlemmer, som jeg skal komme mer inn på senere. Men jeg benytter assimilering her i en modifisert variant om de individuelle somaliere som søker $i$ retning $a v$ en norsk tilhørighet. De kan presentere seg gjennom væremåter som assosieres med denne identiteten, som for eksempel det å gå på norske utesteder. Denne tilpasningsmåten innebærer også svak unngåelse av atferdsmønstre som regnes som somaliske, og distansering fra folk som de regner for å være mer stigmatiserte enn seg selv (for eksempel de som bruker mye tid på khat-kafé).

Et viktig diskursivt tema blant assimileringssøkende somaliere er hvor lang tid en har vært i Norge. Det å ha vært lenge i landet fremheves som noe som styrker identifiseringen med norske verdier. Enkelte av de første som kom til Norge, mener de selv hadde en større åpenhet for de muligheter et liv i et vest- 
lig samfunn kunne gi dem, enn de som har kommet i senere år. Ønsket om å bli integrert, få seg jobb og lære Norge og nordmenn å kjenne var større blant de første som kom, enn den er blant dem som har kommet i senere tid, hevder de. Disse først ankomne distanserer seg også fra de nyankomne ved at de selv har gått grunnskolen eller til og med tatt videre utdanning i Norge, andre fremhever at iveren etter å få seg jobb er større blant de førstankomne enn de sentankomne.

Enkelte av de førstankomne identifiserer seg sterkt med norske verdier, og har en mer sekularisert muslimsk identitet. De liker for eksempel nå og da å ta en øl sammen med andre (sekulariserte) somaliere eller norske kolleger. De forteller at religion var viktigere for dem tidligere, rett etter at de hadde forlatt Somalia. Da praktiserte de ritualet med å be fem ganger om dagen, mens nå spiller religion svært liten rolle i deres liv, ut over at de deltar i den årlige idfeiringen (mest som en sosial sammenkomst).

Osman jobber i en mindre norsk kommune, og er en av dem som skiller mellom de somalierne som kom tidligst, det vil si på slutten av 1980-tallet, og de som har kommet i løpet av de siste årene. «De som kom først har blitt bedre integrert enn de som har kommet senere. Jeg er frustrert over noen av de som har kommet senere som er svært religiøse. De hemmer integrasjonsprosessen, blant annet ved den måten de leder den lokale moskeen på».

De somalierne som vektlegger assimilering, frustreres over andre somaliere som blir svært religiøse etter at de kommer til Norge, mens de i Somalia sjelden var innom moskeen. Det kan se ut til å vare klasserelatert hvilke somaliere som ønsker å assimilere seg og som distanserer seg fra dem som søker trygghet ved å tilbringe tiden sammen med andre somaliere på kafeen eller i moskeen. Blant dem jeg har intervjuet (og dem jeg har samtalt med) gjelder det sæerlig middelklassesomaliere, som er ansatt i offentlige etater og/eller holder på med utdanning på høgskole eller universitet. ${ }^{3}$ De definerer den gruppen av somaliere som kom først som ressurssterke individer, og mener at mange av dem som har kommet senere har mindre utdanning og større problemer med/eller mindre interesse av å finne sin vei inn i det norske samfunnet. ${ }^{4}$

Det at de tidligst ankomne flyktninger definerer seg i motsetning til de som har kommet senere, er et velkjent mønster blant flyktninger fra andre nasjonaliteter også (jf. Portes \& Rumbaut 2001). De som kommer senere kan true det positive selvbildet som de tidligere ankomne flyktningene har, i forhold til å ha lært seg språk og funnet sin vei inn i vertslandets samfunn og kultur. ${ }^{5}$ De som kommer senere og starter med blanke ark, kan oppfattes som truende fordi de lett kan bidra til det negative bildet som går igjen i medias fremstilling av gruppen, med fokus på manglende integrasjon osv.

Uavhengig av ankomsttidspunkt, er det visse væremåter blant somaliere 
som de assimileringssøkende somaliere distanserer seg fra. Khat-tygging er et diskursivt tema som somaliske kvinner ofte er opptatt av, og også blant de assimileringssøkende mennene er dette temaet viktig. De distanserer seg fra somaliske menn som tilbringer tiden på kafé og tygger khat. De mener khat-tyggingen forårsaker mange problemer. Den bidrar til å bryte opp familier fordi kvinnene ikke ønsker å fortsette leve sammen med en mann som bruker penger på khat og som ikke tar ansvar for barna. Khat er derfor et tema som forårsaker konflikt mellom ektefellene, mener de. Khat-tyggende menn fremstilles som motpolen til det å ta ansvar for sin familie. De fremstilles også som menn som føler seg truet av sine koners nyvunne økonomiske uavhengighet gjennom sosiale stønadsordninger. Khat-tyggende menn brukes som symbol på menn som ikke mestrer tilværelsen i Norge, som søker trygghet i mannsfellesskapet, og tygger khat for å glemme de daglige frustrasjonene.

Harun Hassan (2002) beskriver den samme distanseringen overfor khat-tyggende menn blant somaliske kvinner i Storbritannia. Kvinnene der mottar også sosialstønad og boligstøtte. Kvinner som ønsker å studere, og jobbe hvis mulig, samt å være sosiale og delta i den nye kulturen, distanserer seg fra menn som mener at kvinner skulle være hjemme, lage mat og oppdra barn. Hassan utførte en survey blant 78 somaliere, og fant at $28 \%$ la skylden på khat for de mange skilsmisser mellom somaliske menn og kvinner i Storbritannia. Han siterer en somalisk kvinne som skilte seg fra mannen sin. Hun mener at han nektet å gjøre noe husarbeid eller bidra til familieøkonomien og at han var svak for khat. "Han tygget sammen med andre og kom hjem for å sove», sier hun. "Han tilbrakte aldri tid sammen med meg, mange enslige mødre har hatt det på samme måten.»

Lignende uttalelser er vanlige blant yrkesaktive somaliske kvinner i Norge. Et eksempel er Adan, en kvinne i 50-årene, som har bodd i Norge i 16 år, og jobber i introduksjonsprogrammet for flyktninger. Hun er sint på de somaliske mennene som tilbringer tid i kafeer og på gata på Grønland i Oslo, og så kommer hjem for å sove. Kvinnene deres har det tøft, sier hun. Hun mener politiet burde forby disse mennene og samles i gatene hele dagen, og slå ned på at de tygger khat (som er forbudt ifølge norsk lov).

I denne diskursen blir kategorien menn som bruker tid og penger på khat en ekvivalent til menn som ikke tar ansvar for sine familier og som har en negativ orientering til det norske samfunnet. Somaliske kvinner som tar utdanning, er ofte inne i en likestillingsdiskurs i forhold til hvilke somaliske menn de identifiserer seg med (og eventuelt kan tenke seg å gifte seg med) og hvilke de distanserer seg fra. De ønsker menn som tar ansvar for barn og hjem, og distanserer seg fra dem som bare henger med andre somaliske menn på gatehjørnet eller på kafeen. Også i Somalia har kvinner hatt stor rett til å bestemme og handle, 
som Aud Talle (2003:81) påpeker. Blant nomadene var det kvinner som tok seg av saue- og geiteflokkene, og som flyttet transportkamelene med teltene til nye boplasser, ettersom sesongene forandret seg. I lange perioder levde kvinner alene mens mennene vandret etter kamelflokkene. I det daglige var det derfor også kvinnene som hadde ansvaret for barna (Talle 2003). De unge somaliske kvinnene som ønsker at mennene tar del i samværet og oppdragelsen av barna, ønsker således å bryte med det tradisjonelle familiemønsteret i Somalia.

\section{Hybridisering og kombinasjon av en norsk og en somalisk tilhørighet}

Hybridisering innebærer å søke en balanse mellom (i dette tilfellet) norske og somaliske identifiseringselementer. Som jeg var inne på, er denne varianten også til stede blant dem som velger assimileringsvarianten, så her er det snakk om en gradsforskjell. De som eksplisitt beskriver sitt forsøk på å «balansere mellom to kulturer», er de som mest eksplisitt velger en hybridiseringsvariant, mens de som primært vektlegger sin tilknytning til det norske samfunnet, heller mer i retning av assimilering som tilpasningsmåte. Hybride eller kreoliserte identiteter brukes om bestrebelser på å forene elementer fra ulike etniske identiteter (jf. Phoenix 2002:133). Slike begreper har blitt kritisert de senere tiår, blant annet fordi de tilsynelatende nok en gang kan implisere at folk har én overordnet identitet, eller at de indirekte impliserer forestillingen om to enhetlige kulturer (Werbner 2001). Men jeg bruker begrepet her uten en tanke om at hver av kulturene - norsk versus somalisk - er uforanderlige eller enhetlige. Somaliere selv påpeker at somalisk kultur gir seg til dels ulike utslag i Norge og i Somalia, for eksempel fremheves at enkelte blir mer religiøst rigide i eksil enn i hjemlandet. Normer når det gjelder klesdrakt og oppførsel har i stor grad også blitt strengere i etterkant av borgerkrigen, i og med at Somalia under diktatoren Siyad Barres ledelse var svært sekularisert (Jan Haakonsen, personlig kommunikasjon), tatt i betraktning av at over $90 \%$ av befolkningen var sunni-muslimer.

Unge somaliere som har gått på norske skoler og snakker flytende norsk, sier de ser seg selv som både norske og somaliske, men ofte med somalisk som den dominerende identiteten. De unge somalierne definerer hva det vil si å være somalisk ut fra lojalitet til muslimske normer for klesdrakt og oppførsel (ikke å drikke alkohol, ikke spise svin, at jenter må kle seg ifølge visse regler og at de ikke må ha sex før ekteskap og kanskje ikke gå på fester med norske venner eller være lenge ute om kvelden). Hva det vil si å være somalier er sterkt sammenvevd med hva det vil si å være en god muslim. I tillegg kommer ivaretakelsen av det somaliske språket, som en viktig målsetting. Også enkelte unge har i bakhodet at de en dag kanskje vil reise tilbake til Somalia for å leve der. Da er det både viktig å kunne språket og å ha somalisk/muslimske normer for opp- 
førsel godt internalisert. For de unge som lever i Norge med sine foreldre, er dette med oppførsel også noe som angår foreldrene. De vet at hvis de ikke oppfører seg i tråd med normene, vil andre si at "datteren til ... gjør slik og slik», og så går det ut over moren.

Riyo studerer på universitetet. Hun kom til Norge da hun var fem år gammel:

Jeg føler meg som en somalier som lever $i$ Norge. Jeg kjenner mange nordmenn. Og jeg foler meg som en del av det norske samfunnet. Jeg reiser mye utenlands, og da sier jeg at jeg er somalier, men lever $i$ Norge. Ofte er vi mange som bor på samme sted. Da hender det at jeg forsvarer Norge, det norske språk osv. Dette er mitt hjem. Jeg elsker Oslos gater. Det er mulig å kombinere begge identiteter. Du trenger ikke velge bare én av dem.

Denne kvinnen opplever at hun kombinerer to identiteter, men at den somaliske er den viktigste. Hennes norske identitet er mer lokalt forankret i hjemstedsfølelsen i Oslos gater og i hvor hun føler seg hjemme, mens hennes somaliske identitet er en nedaravet etnisk tilhørighet, som også innebæerer en mer dyptgående lojalitet til Somalia hvor hun ønsker å arbeide i fremtiden i et norsk/somalisk selskap, eller for en ideell hjelpeorganisasjon. Sernhede (2002) ser identifiseringen med lokalstedet istedenfor med ens eget opprinnelsesland eller nåværende land, som typisk for mange innvandrerungdommer. Landet de ble født i er bare et fjernt forestillingsbilde, mens lokalstedet der de lever ofte er vel så viktig for identifiseringen. For Riyo er begge viktige. Hun identifiserer seg med Norge primart ut fra en lokal forankring, mens identifikasjonen med Somalia er en form for forpliktelse med tanke på fremtiden.

Misra understreker også muligheten av å kombinere to identiteter:

Jeg føler meg mer somalisk enn norsk. Men jeg takler begge kulturene godt. Jeg har med meg det beste fra begge. Jeg har mange norske venner, mens tidligere hadde jeg bare somaliske venner.

Jeg spurte om hun kunne spesifisere hva det beste fra begge kulturer var. Fra somalisk kultur mente hun det beste var:

At du bevarer religionen, unngår å drikke alkohol, at du bevarer språket og at $d u$ respekterer foreldrene dine. At du ikke glemmer at du er somalier. At du vet hvem du er, og hvor du kommer fra.

Fra den norske kulturen mente hun det beste var: 
At du kjenner samfunnet her, at du vet hvordan du kan gjøre nytte for deg her, at $d u$ vet hvordan nordmenn er og hvordan samfunnet fungerer. Hvis du blander de to kulturene, blir det bra. Jeg opplever meg ikke som så veldig forskjellig fra mine norske venner. Vi har de samme tankene, de samme problemene med kjxrester osv. Likevel er det viktig å vite hvem du er.

I svarene fokuserer Misra ikke egentlig så mye på hva det beste ved kulturene er, men mer hvilke forpliktelser hun har til den somaliske og hvilke muligheter hun har i den norske. Det å ikke glemme hvem du er, er knyttet til å ikke glemme at du er en somalier. Dette sies ofte som et imperativ "du må ikke glemme...», og kan forstås som en norm som unge somaliere internaliserer fra den eldre generasjonen. Unge somaliske kvinner beretter om lignende uttalelser som noe de hører stadig fra de eldre, som påminnelse av at de ikke må bryte normene for passende oppførsel for en muslimsk jente. Da blir uttalelsen et imperativ som skal holde dem på plass, slik at de ikke skal bli så frigjorte i forhold til kjønns- og seksualitetsnormer som (de i hvert fall tror) norske jenter er. Selv om Misra uttrykker at hun har mye til felles med sine norske venninner, signaliserer hun en form for identitetsmessig forskjell også. Dette gjenspeiles særlig i måten hun snakker om ungdomstiden, da norske venner ble fulle på fest, mens hun syntes festene var kjedelige fordi hun var en av de få til stede som var edru.

Hassan studerer på høgskolen og er gift med en norsk kvinne. Han distanserer seg først og fremst fra de somalierne som ukritisk vil bli norske (de assimileringssøkende) og adopterer enhver standard de møter, og tror at det er greit. Selv er han opptatt av at du må ta stilling til hva som er bra og hva som er dårlig. Han definerer seg i motsetning til de norske som går på pub, mens han identifiserer seg med dem som prioriterer familien:

Mange somaliere misforstår hva det vil si å være norsk. De ser dem som går på puben og tror at det er normen. Jeg prover å lede barna mine i riktig retning. Noen velger å lukke døren helt, istedenfor å rettlede barna. Men det er ikke bra å bli helt isolert. Det er stor forskjell mellom somaliske jenter og norske jenter. Norske jenter er mye mer uavhengige og vant til å uttrykke seg. Somaliske jenter er oppdratt med langt strengere restriksjoner for hva de tillates og hva de ikke tillates.

Denne mannen distanserer seg altså både fra somaliere som ukritisk adopterer alt de tror er typisk norsk, og på den annen side med dem som er så redde for norsk innflytelse at de isolerer sine barn helt. For ham er det viktigste å balansere de negative og positive innflytelsene fra begge kulturer.

Annick Prieur (2004) bruker metaforen «balansekunstnere» i sin bok om 
innvandrerungdom. Men slik ungdom jeg har intervjuet fremstiller det, oppleves det ikke nødvendigvis så vanskelig å ta litt fra hver referanseramme. Unge somaliere uttrykker sin kombinasjon av det norske og somaliske uten nødvendigvis å fremstille identiteter som er i konflikt med hverandre. Dette tilsvarer også hva Sissel Østberg (2003:87) fant blant de unge pakistanerne hun intervjuet. De unge somalierne jeg har intervjuet og samtalt med kommer med uttalelser som "Det er ikke noe problem. Jeg mestrer begge kulturer». De benytter likevel et "oss/dem» skille for å verbalisere erfaringer med forskjeller mellom seg selv og norske medelever på skolen i forbindelse med festing og rus. De deltar på fester, men uten å drikke alkohol selv (enkelte ungdommer drikker også, men mottar negative reaksjoner fra andre somaliere for å bryte normene). Disse erfaringene deler de med muslimske ungdommer fra andre nasjonaliteter. Den avgjørende dikotomien her blir derfor ikke primært somalisk versus norsk, men snarere muslimsk vs. sekulær.

Misra fremhever alder som en distingverende faktor på om en definerer seg som somalisk eller norsk. De som var barn da de kom til Norge, er mer ivrige etter å definere seg som norske enn de som var i sin tidlige ungdom da de ankom landet, hevder hun, og viser til sin egen søskenflokk: Hennes yngste søsken identifiserer seg mest med norsk kultur, mens det motsatte er tilfelle med de eldre.

Jeg har en eldre bror, et år eldre enn meg, og en yngre søster og en yngre bror. Den eldste broren og jeg er mest like. Han definerer seg bare som somalisk. Jeg foler meg litt norsk også; min yngste søster føler bare at hun er litt somalisk, og mest norsk, mens min yngste bror definerer seg bare som norsk. Han har bare norske venner.

Ut fra hennes erfaring er det de som enten er født i Norge, eller kom da de var små barn, som er de mest assimileringssøkende. Senere skal jeg gi eksempler som viser at det ikke alltid er riktig.

Enkelte assimileringssøkende somaliere opplever at de ikke tillates å assimilere seg av nordmenn på grunn av hudfarge. Som en motreaksjon blir de gradvis mer opptatt av sin somaliskhet. En av disse er Salaado, i begynnelsen av 20årene, som sier: «Det er så dumt at jeg alltid må si hvordan jeg føler meg, fordi uansett vil jeg alltid vare somalier. Jeg er hundre prosent somalier. Jeg vil alltid se ut som en somalier». Hun knytter sin opplevelse av å være somalier til sin hudfarge. Som Prieur (2002:62) understreker, er det ikke mulig å flykte fra de sosiale betydninger som kroppen bærer. Hudfarge bærer i seg sosiale betydninger, og disse betydningene gjenspeiler samfunnets dominansrelasjoner mellom svarte og hvite. ${ }^{6}$

En mørkhudet innvandrer minnes stadig på sin minoritetsposisjon i relasjon 
til den hvite majoriteten, og den underliggende beskjeden i spørsmålet «Hvor kommer du fra?» er at «Du hører ikke til her». Å bli spurt om etnisk eller nasjonal tilhørighet kan derfor ha som effekt at den andre blir plassert som ikke-tilhørende. Dette ligner på Stuart Halls (1987:63) autobiografiske analyse av i metaforisk forstand å bli plassert utenfor den britiske nasjon. Men denne opplevde ikke-tilhørigheten tillot ham å stille spørsmål ved og analysere den implisitte rasialiseringen av britisk nasjonal identitet og å problematisere den andreheten som ble konstituert i svarte diasporiske britiske identiteter (jf. Phoenix 2002).

Noen somaliere forteller at de kan føle seg ekskludert både på bakgrunn av hudfarge og på bakgrunn av klesdrakt. Salaado forteller: «I fjor på 17. mai ble jeg intervjuet og ble spurt hvorfor jeg ikke hadde på meg bunad. Jeg sa at jeg ikke gjorde det fordi jeg ikke er norsk. Jeg kan ikke tvinge meg selv til å bli akseptert. Jeg vil alltid være en fremmed.» I denne fremstillingen får Salaado frem at selv om hun skulle poengtert sin tilhørighet til Norge i ytterste konsekvens, som ved å kle seg i nasjonal kostyme, så vil hun være en ikke-tilhørende fremmed. Hun får også fram at det blir feil uansett, enten prøver hun ikke hardt nok å assimilere seg, eller hvis hun skulle prøve det, vil hun oppleve andre nordmenn som uansett aldri vil se henne som norsk, siden hun har mørk hudfarge. Hennes identitetsmessige løsning er å poengtere individualitet, uavhengig av etnisk og nasjonal identitet:

Jeg vil bli akseptert som et individ. Jeg liker ikke å bli spurt hvorfor jeg ikke foler at jeg er norsk for så hore noen andre si jeg er utlending. Uansett hva jeg velger, så blir det ikke akseptert. (...) Jeg forsøker å tilpasse meg, men blir likevel sett som en fremmed fordi håret mitt ikke er blond og huden min ikke er lys.

Salaados problematisering av den tosidige stemplingen fra nordmenn, enten av å ikke være assimilert nok eller av å være en fremmed uansett hvor mye hun prøver å ikke være det, kan ses som en lignende problematisering som Stuart Hall har fremmet av tatt-for-gittheten av rasialiserte inkluderinger av hvite mennesker i nasjonen og rasialiserte utelukkelser av andre.

For somaliere som lykkes med jobb og utdanning, ser ikke slik følelse av ikke-tilhørighet ut til å være like presserende. Det å ha en jobb og en formell utdanning vektlegges både av de assimileringssøkende somalierne og blant dem som legger mer vekt på hybridisering. Mange somaliere mener utdanning er viktigere i Norge enn det var i Somalia, der en persons omdømme kan ha vel så mye å si som de formelle papirer. Selv om det blant annet på grunn av krigen er få somaliere i Norge som har utdanning fra Somalia, er det mange foreldre som ønsker at barna deres skal få en utdanning ut over obligatorisk skolegang. De 
ser videre utdanning som en buffer mot arbeidsledighet og kriminalitet. Men ikke alle deler dette perspektivet. En mor sa at hun hadde ingen tro på utdanning, etter å ha sett så mange somaliere med utdanning som ikke en gang fikk en vaskejobb. Denne moren hadde en mer etnisk inkorporerende tilpasningsmåte til det norske samfunn.

Skillet mellom dem med og dem uten videre utdanning fungerer som en symbolsk markør i forhold til hvordan interne grenser somaliere imellom begrepsfestes. Denne distinksjonen ser ut til å væere viktig innad i flere av innvandrerbefolkningene, som for eksempel blant pakistanere (jf. Andersson 2000:163). Tilsvarende er denne distinksjonen viktig blant nordmenn. For mange innvandrere blir utdanning viktigere enn i hjemlandet, fordi det kan oppleves som en viktig vei til å bli verdsatt på linje med majoriteten. For foreldre kan utdanning oppleves som veien til aksept for deres barn (et slikt syn er selvsagt også høyst til stede hos den hvite majoriteten). Den utdanningen de selv mangler, håper de at barna i stedet kan ta, og således bidra til familiens status og etter hvert også inntekt. Utdanning kan således ideelt sett bidra til sosial mobilitet og et forbedret rykte i offentligheten for minoriteten. For somaliere kan dette behovet ses som en motreaksjon mot stigmatiseringen i offentligheten, men i tillegg er behovet klart relatert til deres forventninger om et godt liv, uavhengig av hvordan de blir møtt for øvrig.

Først og fremst går identifiseringsskillet mellom det å prøve å få seg en utdanning og/eller jobb, og det å ikke en gang prøve det. Abdi, som har vaert i Norge i 17 år og tatt sin høgskoleutdanning her, sier:

De vil ikke gå på kurs, de vil ikke gå på skole. 'Nei, hva er vitsen?' sier de 'Men du har jo ikke prøvd!' (...) Jeg liker ikke sånt, jeg mener at man uansett må vare litt aktiv $i$ forhold til jobb eller utdanning.

Utdanning handler således om å aktivt ville ta del i samfunnet, istedenfor å leve avsondret fra det. Men skillet mellom de som aktivt deltar, og de som ikke gjør det, kan også knyttes til andre kategorier. Misra, som jeg har sitert tidligere, er høgskolestudent. Hun definer seg i kontrast til de somalierne som kommer fra landsbyda i Somalia, de som er for opptatt av klanbakgrunn, eller de som bare er sammen med andre somaliere:

Somaliere er et rart folkeslag. De vurderer folk ut fra klanbakgrunn og hvordan de kler seg. Det er stor forskjell mellom de som kommer fra de store byene i Somalia og de som kommer fra landsbygda. De fra byene har mye lettere for å bli integrert enn de fra landsbygda. Hvis du kjenner språket og har gått på skole i Norge, og vet hvordan samfunnet fungerer, er det ikke noe problem. Da bidrar du til samfunnet. Men 
det er mange unge som strever falt. Sxrlig de som kom hit på egen hånd. Mange av dem er bare sammen med andre somaliere.

For Misra er det viktig å ha somaliske venner på tvers av klansgrenser. Hun identifiserer seg først og fremst med somaliere fra de store byene, som tar lengre utdanning.

Noen somaliere, som Misra, understreker distinksjonen mellom de med urban bakgrunn som en motsetning til de med rural. De urbane er mer utdannet, integrerer seg lettere og er ikke like opptatt av klan. Lignende distinksjoner hørte Andersson blant sine pakistanske informanter, som tok universitetsutdanning. Tilsvarende dikotomier er også høyst levende i det norske samfunnet, der folk fra byene ser seg som mer sofistikerte enn de fra landsbygden, og ofte også som mer utdannet. Andersson (2000:164) har funnet at norsk-pakistanere som tar utdanning, konstruerer de som ikke har videre utdanning (og eventuelt er analfabeter) og folk med rural bakgrunn som negative referansegrupper ut fra et ønske om å regnes som individer av like mye verdi som etniske nordmenn Mange somaliere jeg har intervjuet, sier at de ikke vil dømme (de som for eksempel ikke tar utdanning), men at de i hvert fall identifiserer seg med de som tar utdanning.

Problemet for mange somaliere er at selv om de idealiserer videre utdanning har de vært i Norge så kort tid at veien til målet kan synes lang og vanskelig tilgjengelig. Utdanningsmålet er til sammenligning enklere for en del pakistanere, som har hele sin skolegang her, og har foreldre som er i jobb. Jimale er en somalisk ung mann som strever med å mestre veien til utdanning og jobb. Han var tidligere innblandet i kriminalitet og dop. Men han ble far for noen år siden, og ønsker å gjenoppta kontakten med sønnen, som moren (som er norsk) nekter ham, fordi han ikke finner ut av livet sitt. Han kom til Norge alene som ung gutt. Nå vil han ikke lenger ha å gjøre med andre unge somaliere som driver med kriminalitet og narkotika. Han bor i et kollektiv og er lei av at andre dukker opp på nattestid og fester, så han ikke får sove. Han sier han føler seg vel nå, fordi nå er han på vei til målet sitt, som er å få seg jobb og utdanning. "Jeg hater å gå på sosialkontoret», sier han. Han mistet praksisplassen sin fordi han ikke møtte opp til avtalt tid. Likevel beskriver han Norge som det beste land i verden når det gjelder jobbmuligheter. "Jeg liker de somalierne som hjelper hverandre. Jeg liker ikke de som ikke følger reglene og som stjeler fra folk. Jeg liker de som er rolige og som går opp trappen, ikke ned.»

Jimales historie illustrerer hvor tøft det er å finne seg til rette i Norge, når man kommer hit som enslig mindreårig, uten tidligere skolegang, eller noen til å hjelpe seg. Hjemme i Somalia er fortsatt foreldrene hans, som har store forventninger til ham. Han vil ikke skuffe dem. Han gjør alt han kan for å få kon- 
takt med sønnen sin igjen. Han får en del hjelp av en somalisk mann som jobber for kommunen, og fylles nå av håp om at han skal få orden på livet slik at han kan få gjenoppta kontakten med sønnen igjen. Han har behov for å distansere seg fra de somalierne som ledet ham i feil retning i fortiden, og identifisere seg med dem som "går opp trappene", som får seg utdanning, som hjelper andre, og som holder seg rolige.

Resignasjon og sinne er for mange de naturlige reaksjoner på lange perioder der de har forsøkt å lykkes med utdanning eller å få seg jobb, uten å finne noen åpen dør. Noen av disse vil etter å ha forsøkt assimilering eller en hybridisering, etter hvert gå over til etnisk inkorporering, som jeg beskriver næermere i neste kapittel.

\section{Etnisk inkorporering og betoningen av somalisk tilhørighet}

Etnisk inkorporering er den prosessen der etnisk medlemskap gjøres relevant for mobilisering av gruppebevisstheten og felles politisk handling vis-a-vis majoritetsbefolkningen (Barth 1969, Eidheim 1987:68). Eidheim beskriver etnisk inkorporering som en kollektiv tilpasningsform, i motsetning til den assimilerende, som er individuell. For somaliere har etnisitet vært et viktig tema lenge før borgerkrigen og strømmen av somaliske flyktninger ut av Somalia. På tross av konfliktene mellom ulike klaner, blir somaliere ofte fremstilt som et svært homogent folk. Alle somaliere - bortsett fra noen få minoriteter - deler samme språk og samme religion (sunni-islam). Språkforskjellene er størst mellom nord og sør, men de fleste forstår standard somali, og kan derfor kommunisere greit med hverandre (jf. Lewis 2002:5). Koloniseringen av Somalia medførte fiktive grenser som skilte mange etniske somaliere fra det territoriet som ble definert som somalisk. Følgelig er det mange mennesker som har levd hele livet i Djibouti, Kenya og Etiopia, men som likevel regner seg for å være somaliere. Et nasjonalt statsborgerskap har ikke noen sterk innflytelse på somalieres identitet, de er somaliere selv om de for eksempel har vokst opp i Kenya. (Somalia har ikke vært noen nasjonalstat etter at diktatoren Siyad Barre måtte flykte fra landet i 1991.)

Selv om etnisitet er en viktig identifikasjonsenhet for somaliere, varierer det hvor sterkt hvert individ betoner sin identitet med andre somaliere, med sin egen klan eller med en annen avgrenset kategori av somaliere (for eksempel de med lengre utdanning). Det varierer med andre ord hvor bredt det etniske defineres - om det avgrenses til egen klan, Sør- eller Nord-Somalia, alle somaliere, eller på tvers av nasjon og etnisitet, som når man definerer seg som muslim eller afrikaner.

I motsetning til det Eidheims teori tilsier, finner jeg blant de jeg har intevjuet som driver velferdsarbeid blant somaliere (felles politisk handling og 
deltagelse i somaliske kollektiver), at de $i k k e$ har en ensidig somalisk identitet eller levemåte, men mer betoner sin tilhørighet i Somalia og Norge. På den annen side finner jeg at noen av dem som ensidig betoner sin somaliske identitet, ikke deltar i rent somaliske miljøer eller engasjerer seg i felles politisk handling. For å gi et eksempel på det første, har vi Sharif, som er leder i en somalisk interesseforening, men som definerer seg slik:

Jeg definerer meg som norsk-somalier. (...) Jeg er halv/halv, ikke sant. (latter). Jeg har vært kanskje mer $i$ Norge enn jeg har vært $i$ Somalia nå etter hvert. Jeg legger til at jeg har to land, jeg hører til Norge og jeg er født i Somalia. Jeg har to språk, jeg har somalisk og norsk. Sånn tenker jeg.

På den annen side har vi altså enkelte, som Sasha, som betoner sin somaliskhet, uten nødvendigvis å forene seg i felles politisk handling eller i somaliske kollektiver. Et tema som hun fremhever, er at det føles enklere, mer naturlig, å tilbringe tid sammen med somaliere enn med nordmenn. Sasha, som var integrert i den forstand at hun jobber på sykehjem, og ønsker å ta universitetsutdanning, fremhevet behovet for å være sammen med somaliere:

Det [å vare sammen med nordmenn] blir ikke samme folelse, det kan ikke sammenlignes med når jeg er sammen med somaliere, det er lettere for meg, da kan jeg tilpasse meg mer. Da skjer det helt automatisk, men når du er sammen med andre grupper, så blir det litt uvant. (...) Det er vanskelig å forklare, men det er helt i naturen, det kommer naturlig. Det eneste jeg vet er at det ikke er samme folelse. (...) For vi prater hele tiden på vårt språk og vi kan minne oss på barndommen og snakke om kulturen vår og vi kan det og det og det. (...) Det jeg foler er at norske er, jeg vet ikke om de er redd for utlendinger eller hva det er, men ... Folk som er veldig rolige, stille, de er ikke lett å komme inn på. Litt annerledes fra oss i fra Afrika og andre deler av verden. Det er sånn det føles.

Sasha kan forstås som tilhørende den somaliske overklassen, idet faren hennes hadde et høystatusyrke som religiøs dommer. Moren jobbet med å lage mat til mottagelser for regjeringen i den tidligere somaliske republikken (før borgerkrigen). Denne klassebakgrunnen kan bidra til å kaste lys over Sashas eget valg av å ta høy utdanning, samtidig som hun ikke velger å assimilere seg. Det religiøse fellesskapet er viktig for henne. Hun ber fem ganger om dagen, og en periode sluttet hun i jobben fordi hun ikke fikk be i løpet av arbeidsdagen:

Da ble jeg veldig bekymra. (...). Når jeg ikke ber så har jeg mye bekymringer og dårlig samvittighet og tenker at det er ting du burde gjort som du ikke gjør. (...) Du vil 
praktisere din tro, og det er det vanskeligste. Hvis jeg hadde vart $i$ et islamsk land eller folka hadde det til felles slik at alle kunne be, så hadde det vart lettere, fordi da har du flere som har det som deg, som ber, og som går. Når du er helt alene eller det bare er et par personer, så blir det vanskelig.

Hun fastholder med andre ord en aktiv muslimsk identitet, selv om det på jobben blir en ensom tilhørighet. Når det gjaldt etnisk identifisering, var Sahsa klar på at hun aldri kunne bli noe annet enn somalier, og at heller ikke hennes fremtidige barn skulle ha en forestilling av å tilhøre begge kulturer:

Det er en identitet du ikke kan miste, uansett hva du blir og hvordan du lever. Men det er ingen som kan erstatte eller slette at du er somalier, og bli norsk. Det er umulig, jeg kan ikke bli norsk fordi jeg er somalier, og sånn er det.(...) Det kan hende at min levemåte blir akkurat som den norske måten, men min identitet, hvor jeg kommer fra er det ingenting som kan erstatte. (...) Mine barn, for eksempel hvis de blir fodt her $i$ Norge, så har de navlestrengen her. Så de kan si at de er født her og de er norske. Men jeg kan fortelle dem at rottene deres er fra Somalia. Jeg vil gjerne lare dem den kulturen de tilhører, den som tilhører moren eller faren deres. Jeg vil ikke at mine barn skal fole at de er norsk sammen med norske og når de moter somaliere at de foler seg: «Ja, du er ikke somalisk». Jeg vil at de skal velge ett sted, at de ikke må tenke på begge. At de har et valg, at de kan velge hvor de vil vare. (...) Jeg kan ikke så mye om Somalia, og jeg skulle onske at jeg kunne mer, men jeg foler meg alltid somalisk.

I tillegg til den somaliske identiteten, var altså den muslimske viktig for henne, og den gjenspeilet seg i klesdrakt:

Når jeg bruker hijaben så kan man merke det med en gang at jeg tilhører islam. Fordi hijab viser det med identitet, den viser at jeg er en muslimsk jente. [Når jeg bruker hijab viser] alle de eldre at de er stolte, at jeg gjør noe som er bra for meg.

Ved å kle seg muslimsk får somaliske kvinner positive bekreftelser fra andre i det somaliske miljøet. Men de somaliske kvinnene som bærer lange muslimske sjal og er oppriktig opptatt av å følge muslimske kjønnsnormer kan noen ganger være mer åpne for norsk identifisering enn de ytre trekkene (klesdrakt og ritualer) skulle tilsi. Adan er en kvinne i 50-årene, som jobber med integrering av flyktninger. Hun bærer alltid langt sjal og lange vide klær. Samtidig definerer hun seg som norsk. Hun beskriver dette som en motreaksjon, for å få folk hun møter til å tenke mer kritisk over kategoriene de har i hodet. Når folk spør om hun er somalier, sier hun altså, «nei, jeg er norsk». Ofte blir folk litt forvirret 
over dette svaret. Adan beskriver sin identifisering som norsk mer som en bevisst motreaksjon enn en dypfølt identifikasjon med og lojalitet til norsk kultur og væremåte. Hun er svært kritisk til det hun oppfatter som nordmenns liberale holdning til alkohol og sex. Hva hun ønsker er altså å provosere folks forhåndsoppfatninger. Hun har således en mer uklar etnisk inkorporering. Hun lever og kler seg som muslim og somalier, men kaller seg likevel norsk. Ved en slik fremgangsmåte poengterer hun at man faktisk kan velge en fremtid i Norge, men likevel fastholde sin etniske forskjellighet. Man kan kalle seg norsk, men således inkorporere en somalisk/muslimsk levemåte i denne tilhørigheten.

Mens klesdrakt er en måte å vise muslimsk/somalisk tilhørighet på for kvinner, er det mannsfellesskapet på kafé som fremheves av en del somaliske menn som en viktig vei til etnisk tilhørighet. En av disse er Abdalla, på litt over 40 år. Han er nå og da innom kafeene for å slå av en prat og høre siste nytt fra Somalia. Men han distanserer seg fra de mennene som bruker mye tid i kafeene. Han er nemlig også opptatt av å bruke tid på familien sin, og være med å veilede barna. Abdalla, som ikke har noe utdanning ut over grunnskolenivå, har tidligere jobbet som kjøkkenhjelp på et hotell. I mine gjentatte samtaler med ham, understreker han at han vil gå "den norske veien", og identifiserer seg med de somalierne som vil integrere seg. Likevel mener jeg han foreløpig primært har en etnisk inkorporeringstilpasningsmåte. Jeg skal nevne noen grunner til det.

For det første ønsker han ikke at kona skal delta i introduksjonsprogrammet for flyktninger, hvor hun har tilbud om norskopplæring (hun sier også selv at hun ikke vil det). Han mener at hun burde være hjemme og ta seg av barna (de har åtte barn, hvorav fem går på skolen) og lage mat. Han har selv ikke prøvd å få seg noen ny jobb etter at han ble oppsagt i den forrige. Han syntes oppsigelsen var urettferdig. Nå mener han at han kommer bedre ut av det med forskjellige stønadsordninger (sosialpenger, barnetrygd og kontantstøtte). Men han holder seg stadig aktiv ved å delta på forskjellige arbeidsmarkedskurs m.m. Barna går på koranskole på lørdagene og hans eldste datter på 13 år bruker hijab. Også de to yngste døtrene bruker hijab når de skal på koranskolen. Men de får ta den av når de er hjemme og når de skal på den ordinære skolen. I betydningen assimilering, er det klart at han, hans kone og hans barn ikke følger «den norske veien».

Hans opplevelse av å identifisere seg med "den norske veien» inkluderer andre ting: Blant annet at han kontrasterer seg til de som er muslimske fundamentalister og også, som nevnt, med de somaliske mennene som tilbringer mye tid i kafeene istedenfor å ta ansvar for å veilede barna og hjelpe i familien. Abdalla plasserer seg på denne måten som en som ønsker å ta ansvar for familien, men som blant annet gjør det ved ikke å jobbe ( «da får jeg mer tid til å veilede barna») og som nå og da blir med mennene på gatehjørnet på Grønland 
for å slå av en prat, selv om han ikke vil oppfattes som så negativ til det norske som dem. Abdallas posisjon kan ses som svart rasjonell: Han drar maksimal nytte av det sosiale stønadssystemet, og på denne måten får han og hans kone en mulighet til å tilbringe tid med sine barn, samtidig som de slipper å oppleve diskriminering på arbeidsmarkedet. Han bruker noe tid i det mannsdominerte miljøet nede på Grønland, for å få litt sosial avveksling, for å dele sine frustrasjoner over livet i Norge, samtidig som det gir ham en liten smak av det Somalia, som han har forlatt og som han savner.

For noen er veien inn i det norske samfunn veldig vanskelig tilgjengelig. Selv om de forsøker, får de ikke de jobbene de ønsker, og de blir ikke kjent med noen norske. Negative erfaringer på arbeidsmarkedet, i kontakt med ulike offentlige kontorer og på skolen, kan føre til at en orienterer seg mer mot egne tradisjoner og velger å leve på siden av det norske samfunnet, ved å søke fellesskap med andre arbeidsløse somaliere i kafeer eller på gatehjørnet (for eksempel på Grønland i Oslo). Foreløpig tilhører Abdalla denne kategorien, men med sin sympatiske innstilling til mer integrerte somaliere, er det ikke umulig at hans posisjon blir preget av større delaktighet i det norske samfunn på lenger sikt.

Negative erfaringer blant annet på arbeidsmarkedet kan imidlertid vare medvirkende til at somaliere som opprinnelig har søkt assimilering, etter hvert går over til å betone etnisk inkorporering. Noen søker også videre til andre land som har større og mer etablerte somaliske bosettinger enn Norge, som England, som har hatt somaliske innvandrere siden begynnelsen av 1900-tallet, på grunn av den britiske koloniseringen av Nord-Somalia. ${ }^{7}$ En av dem som reagerte ved å bryte opp og dra til England, er Safia, en kvinne i slutten av 30årene, som deltok på et norskkurs, der hun opplevde at hun ikke fikk be når hun ønsket:

Jeg synes det er vanskelig å godta at jeg ikke får be på kurset. A be er halve livet mitt! Jeg horte at det var religionsfrihet $i$ Norge, men det stemmer ikke. Dette er veldig vanskelig for meg, så jeg vurderer å slutte på kurset. Jeg får 5.000 kroner hvis jeg fullforer kurset, men hvis jeg må velge mellom 5.000 kroner og å be, så vil jeg velge å be.

Det blir tydelig hvor ektefølt dette var for kvinnen fordi et par måneder senere tok hun med seg barna og flyttet til London. Hun orket ikke leve i et land der hun ble nektet retten til å leve og praktisere på den måten hun gjorde i Somalia. Betoningen av den religiøse tilknytningen kan ses som en vanlig tilpasningsform blant de somaliere som ikke så lett finner veien inn i det nye samfunnet. McMichael (2004) skriver om somaliske kvinner i Melbourne som opplever islam som en kontinuerlig forbindelse med deres bakgrunn fra Somalia. Religionen opprettholder en følelse av identitet og tilhørighet. I denne iden- 
titetsbetoningen blir det viktige å ha en kontinuitet med det man forlot, mer enn å finne en ny identitet tilpasset de nye omgivelsene.

Etnisk inkorporering trenger ikke bare være knyttet til fellesskap med somaliere i Norge. For somaliere er forpliktelsen til slektinger i andre land sterk, således er det også klare transnasjonale elementer i deres identifisering. Ahmed, en somalisk helsearbeider, illustrerer en erfaring som mange somaliere deler (dette gjelder også flyktninger fra mange andre nasjonaliteter):

Jeg har en far og en bror i Somalia, så vel som en onkel og en tante. De bor på ulike steder. Så har jeg en mor og en bror $i$ USA. Og så har jeg en bror $i$ Canada og en $i$ Göteborg. Det er mange somaliske familier som er brutt opp på denne måten.

Somaliere i Norge har slektninger i mange vestlige land, som England, Canada, USA, Sverige, Tyskland osv. Det som Ulf Hannerz (1992: 39) skriver generelt om kultur er spesielt slående som en beskrivelse av somalisk kultur, at det som et kollektivt meningssystem er mest knyttet til sosiale relasjoner og nettverk og kun indirekte til sted. Å være somalier er således en identitet definert av å forbli knyttet til somaliske slektninger eller det somaliske miljøet, mer enn nødvendigvis å opprettholde en sterk forbindelse til Somalia.

Tanken om én gang å kunne vende tilbake til Somalia for å leve der gir en følelse av trøst og trygghet. En slik «myte om tilbakevending» som Gardner and Shukur (1994) kaller det, kan imidlertid komme i veien for ens forsøk på å bli integrert i vertslandet. Dette å først og fremst idealisere og identifisere seg med ens eget opprinnelsesland, kan i tråd med Herbert J. Gans (1996:146) kalles symbolsk etnisitet. Denne orienteringen kan ifølge Gans gi seg uttrykk på mange ulike måter, men først og fremst i en nostalgisk forpliktelse til opprinnelseslandets kultur og i kjærlighet til og stolthet over tradisjonen, som kan føles uten nødvendigvis å inkorporeres i dagliglivet. Dette tilsvarer hvordan de etnisk inkorporerende somaliere tematiserer sin somaliske tilknytning som en stolthet og en identitet, som de ikke nødvendigvis vet hvordan de uttrykker konkret i det daglige, men som likevel er en viktig del av deres bevissthet.

\section{Generasjonsforskjeller i tilpasningsmåte og identifisering - ett eksempel}

Et velkjent mønster i somaliske familier er at foreldrene betoner etnisk inkorporering, og reagerer med bekymring, formaninger og kanskje til og med press på at barna velger enten en assimilering eller hybridisering. Men vi ser også motsatt mønster. Hilaal er en mann i 50-årene som jobber i en offentlig etat, og liker å gå ut med sine norske kolleger, eller med andre somaliere som er like sekulariserte som ham selv. Tidligere var han også gift med en norsk kvinne. Sønnen hans, derimot, identifiserer seg ikke med Norge i det hele tatt, men 
med Afrika. Han har en kamerat som også har et negativt syn på Vesten, men som først og fremst er opptatt av et muslimsk fellesskap på tvers av etniske grenser. Begge guttene har en mer antagonistisk måte å verbalisere den kulturelle forskjellen mellom somaliere (eller muslimer) og norske. De fordømmer norsk (eller vestlig) kultur. Hilaal skriver dette om sin sønn i en e-post til meg:

Han hadde noen få norske venner da han var liten gutt. Men nå har han bare venner med innvandrerbakgrunn. Jeg kritiserte ham for det og sa at han ikke ville komme til å lare norsk hvis han bare hadde norske venner. Jeg synes han er snill og god, men det bekymrer meg at han bare snakker om norske på nedsettende måter. Vi diskuterte at det ville bli vanskelig for ham å lykkes $i$ dette samfunnet hvis han ikke liker det. Han liker ikke Bush, han liker ikke israelerne; han synes hvite gjorde og gjør mye galt $i$ denne verden. Han tror ikke på vestlig psykologi, ikke en gang på vestens vitenskapelige metoder. Det skremmer meg. Larerne har sagt at han er den flinkeste eleven på skolen, men han nektet å bruke talentet sitt. Han fullførte ikke videregående og nå jobber han i en butikk $i$ Oslo sentrum som eies av en muslimsk mann. Jeg foler at han forakter utdanning - det vil si vestlig utdanning. Ikke spør meg hvor han har den ideen fra. Etter 11. september hadde jeg en alvorlig samtale med ham. Jeg lot ham få vite at jeg ikke vil miste sønnen min til en hellig krig mot den vestlige verden. Jeg nevnte den måten Al-Qaeda rekrutterer unge, naive gutter og hjernevasker dem til å utfore grusomme handlinger mot vestlige land. Han trostet ved å si at han ikke hadde planer om å starte krig mot noen $i$ denne verden. En annen somalisk gutt på min sønns alder, og hans venn, forteller meg at han ønsker å dra til Afghanistan for å slåss mot amerikanerne og europeerne der. Vi hadde en lang prat om dette. (...) Det jeg skrev til deg om min sønn, kan du skrive i rapporten din. Jeg synes det er interessant og du kan sette det $i$ en større sammenheng. Jeg synes det disse guttene tenker er viktig i forhold til spørsmålet om identitet. I min generasjon var det en xre, en fordel, prestisje eller hoyt ansett å komme til Europa og Amerika for å studere. Hva er det som får våre sønner til å forakte mye av det Vesten står for? Dette er tankevekkende, men på samme tid skremmende synes jeg.

Hilaals sønn ville ikke bli intervjuet. Som Hilaal skrev til meg «Han føler seg brydd når folk han ikke kjenner snakker til ham. Han er forferdelig sjenert». Men jeg ser ingen grunn til å tvile på Hilaals fremstilling av hva sønnen sa. Problemet er mer at jeg ikke kan stille spørsmål til sønnen for å få utdypet standpunktene. Jeg vet ikke hvor vanlig en slik orientering er blant somaliske gutter i Norge, men jeg tar denne historien som et tegn på at det i hvert fall er noen somaliske ungdommer som går svært langt i å motidentifisere seg med Norge og den vestlige verden. Tidligere har Hilaal fortalt meg at hans sønn identifiserer seg med Afrika, ikke Somalia, og at Nelson Mandela og Haile Selassie er hans idealer. ${ }^{8}$ 
For Hilaal var det i begynnelsen litt provoserende at sønnen idealiserte Haile Selassie, fordi han var fra Etiopia. Hilaal ble født i Ogaden, som tidligere hørte til Somalia, men ble overtatt av Etiopia i løpet av Ogaden-krigen på 1950-tallet. Når Hilaal var syv år gammel, flyktet han med familien sin til den nordlige delen av Somalia. De mistet grunnen sin på grunn av krigen. Han har derfor hatt et hatefullt syn på Etiopia. Men Hilaal fremholder at han ikke føler det slik lenger, og nå liker han de rastafarianske fargene som er de samme som fargene i det etiopiske flagget; rød, grønn og gul. Hilaal er skuffet over Somalia, og Somaliland, og orienterer seg mer mot Afrika enn tidligere. Han er også sint på somalieres rasistiske syn på folk fra andre afrikanske land, som er mørkere i huden og har et mer tradisjonelt afrikansk utseende enn somaliere, som er brune i huden og kanskje med en mer arabisk innflytelse utseendemessig. Han forteller om Somalias tidligere deltagelse i den jemenittiske slavehandelen. Den skolen som Hilaal gikk på da han var barn, ble under slavetiden brukt til å oppbevare slaver før de ble sendt videre til Europa og Amerika. «Jeg skammer meg over denne delen av Somalias historie», sier han. "Jeg skammer meg over den måten somaliere ser på folk fra andre deler av Afrika» (sør og vest).

I dette tilfellet ser vi at Hilaal som kom til Norge som voksen på slutten av 1980-tallet, idealiserer og identifiserer seg med Vestens muligheter, mens sønnen hans som kun var barn da de kom til Norge, forakter Vesten. I England på 1970-tallet, forekom noen av de samme generasjonsforskjellene blant innvandrere fra Jamaica. Dick Hebdige (1979:4lff) beskriver den første generasjonen av karibiske innvandrere som noen som hadde et ønske om å lykkes, å gå gradene, i den betydningen som tradisjonelt var lagt av det hvite samfunnet, mens unge mennesker fra annen generasjon, de ungdommene som gikk på britiske skoler, i stedet begynte å kultivere et mer åpenbart afrikansk «naturlig» image, ved å følge den trajektorien som Hebdige kaller "tilbake til Afrika», markert av rastafariansk estetikk med vekt på motstand og svart identitet.

Denne løsningen, å overdrive de etniske identitetene, om nå den primært defineres som somalisk, eller som muslimsk eller afrikansk, kan ses som en motreaksjon til opplevelsen av utstøting i det norske samfunnet. Dette illustrerer det faktum at identitet og makt er relatert til hverandre (jf. Phoenix 2002: 134). Marianne Gullestad (2003) analyserer lignende historier nedskrevet av unge mennesker i Norge som «har valgt å omfavne den territoriebaserte identiteten som deres utseende peker mot innenfor en norsk eller europeisk sammenheng». Gullestad argumenterer med at avstamning skaffer et "naturlig» anker ikke bare for å bringe sammen atskilte og motstridende identiteter i ett sammenhengende selvbilde, men også for å helbrede angrepne identiteter. Jeg tror Gullestads tolkning har mye for seg. Slike reaksjoner som den Hilaals sønn og vennen hans har, er sinte reaksjoner mot en vestlig verden som alltid vil 
fortsette å definere dem som svarte og som forskjellige og Vesten som bedre og mer sivilisert enn resten av verden. Å gi opp Norge eller Vesten generelt som enheter å identifisere seg med, og i stedet overdrive enten en afrikansk eller en muslimsk identitet, er en reaksjon på å føle seg angrepet. Og grunnen til at disse to guttene enten velger Afrika eller et fellesmuslimsk samfunn som sitt identifikasjonsanker, er at de distanserer seg fra sin bakgrunn som somaliere, på grunn av det negative stigmaet som har blitt knyttet til denne kategorien. De søker derfor etter alternative måter å definere sin tilhørighet, noe som resulterer, i likhet med det Gullestad skriver om de historiene hun analyserer, i at de snur stigmaet ved å ilegge det positiv verdi. Men den positive verdien ilegges ikke det å være somalier, som er kategorien som ble stigmatisert i utgangspunktet, men i stedet i det å identifisere seg med en mer generell kategori (afrikanere eller muslimer) og ilegge denne bredere definerte tilhørigheten positiv verdi. I og med at islam er en verdensreligion, tillater den dem både å uttrykke sin frustrasjon med det hvite samfunn generelt og å forene seg med en verdensomspennende trend som knytter dem økonomisk og finansielt til det globale Umma (den islamske nasjon) i andre muslimske land (jf. Gardner and Shukur 1994:163).

Men mange somaliere opplever også fordommer og diskriminering knyttet til at de er muslimer. Etter hendelsene 11. september, har stigmatiseringen og mistenksomheten rettet mot muslimer intensivert. Også kategorien afrikaner eller svart forårsaker fordommer og diskriminering. Stigmatiseringen av svarte har en lang forhistorie. W.E.B. Du Bois (1903/1994) skrev i begynnelsen av forrige århundre om at å være svart i Vesten tvinger deg til en "dobbel bevissthet» . I formell betydning er du medborger og altså del av nasjonalstatens fellesskap. På den annen side blir du som svart definert som utenforstående, annerledes og ikkeinvolvert i det kulturelle fellesskapet (jf. Sernhede 2002:94).

\section{Diskusjon}

Som vist i denne artikkelen, har somaliere i Norge mangfoldige måter å identifisere seg på. Noen ser seg på samme tid som norske og somaliske, mens andre ser seg som bare somaliske eller bare norske. Noen oppfatter sin identitet som noe de ikke kan velge, som Salaado, som opplever at hudfargen medfører at hennes somaliske identitet er den mest dominerende, uansett hvor integrert hun blir. Andre identiteter kan forstås som politiserte etniske identiteter (jf. Bradley 1996), fordi de frembringer et grunnlag for handling og en kollektiv organisering. Dette er tilfellet med Hadjis identifisering som del av et muslimsk broderskap og Hilaals sønns identifisering med Afrika og med rastafarianisme.

Blant unge somaliere i Norge som har gått på norske skoler, ser hybridisering ut til å være vanligere enn slike «tilbake til Afrika» eller «Muslimer mot den vest- 
lige verden» identiteter, som vi ser hos Hilaals sønn og vennen hans. Mine intervjuer med somaliere med ulike posisjoner i det norske samfunn viser likevel at tilknytningen til Somalia er sterk også hos somaliere som velger å assimilere seg. For de unge somaliere som har gått mange år i norsk skole, og som er født her, eller var små barn da de kom hit, kan bildet av Somalia være idealisert. Somalia er for dem en annen verden enn den norske de har bodd i største delen av sitt liv, og som de har et mer innvendig forhold til (jf. Sernhede 2002:93).

Den sårbare posisjonen som somaliere i Norge befinner seg i, og som er et resultat av segregering, diskriminering og stigmatisering, fører til en identitetsnavigering sentrert rundt behovet for å distansere seg fra de somalierne som passer til det negative offentlige bildet, og et behov for å definere sitt eget bilde av hva det betyr å være somalier, som en kontrast. Den offentlige debatten bidrar til definisjonen blant somaliere av hvilke kategorier som er sentrale. I det store og hele ser det ut til å være bred enighet om hvilke kategorier som er sentrale å identifisere seg med eller i motsetning til, men stor variasjon i om kategoriene ilegges positive eller negative egenskaper. Det som en etnisk inkorporeringssøkende somalier vil definere som menn som holder seg til sine egne, og ivaretar det somaliske fellesskapet, vil en assimileringssøkende kvinne kunne se på som menn som bruker for mye tid utenfor familien, og ikke tar nok andel i de hjemlige pliktene. Det som en religiøst aktiv somalier ser som ungdom som har «blitt for norske» eller som kler og oppfører seg for lettsindig, vil en assimileringssøkende somalier se som en som bare er ung, og oppfører seg slik unge mennesker forventes å gjøre. Således ser vi at hvilken betoning de ulike somaliere gir ulike livsstiler og tilpasningsmåter henger sammen med den relasjonen de selv har til det norske samfunn, og om de vil assimileres eller om de heller vil ivareta sin etnisitet (etnisk inkorporering).

Hva det vil si å være somalier vil være forskjellig i Norge og Somalia. I Norge blir oss/dem-dikotomier benyttet for å konstruere hva det vil si å være somalier for en selv i motsetning til for andre somaliere og også i kontrast til hvordan norske oppfører seg. De som søker assimilering betoner blant annet forskjeller ut fra formell utdanning og stabil jobb: de som aspirer mot videre utdanning og jobb versus de som ikke gjør det, eller de som har utdanning (og/eller jobb) og de som ikke har det. De som søker etnisk inkorporering tematiserer forskjeller ut fra religion, ved at de definerer seg negativt i forhold til dem som er mer sekulære, eller som ukritisk adopterer alt i norsk kultur. På den annen side definerer de assimileringssøkende og mer sekulære seg også negativt i forhold til dem som er svært religiøse. De ulike identitetsposisjonene blir forståelige ut fra hvorvidt den enkelte ønsker assimilering i det norske samfunn, eller om de ønsker å bevare så mye som mulig av sin somaliske og muslimske identitet selv om de bor i et land med en annen kultur. 
Vi ser ofte at de assimileringssøkende distanserer seg fra landsbygdbakgrunn, khat-tygging, opptatt av klan, hijab, arbeidsløs, ingen utdanning. De identifiserer seg med å komme fra de store byene i Somalia, være blant de første som kom til Norge, ikke være opptatt av klan, samhandle med norske, ta eller ha formell utdanning, jobbe, ikke bruke (eller synes jenter ikke trenger å bruke) hijab, osv. De hybridiseringssøkende opererer med mange av de samme dikotomiene, men er opptatt av å kombinere religiøs forpliktelse med å integreres i samfunnet. De etnisk inkorporerende derimot, har ofte motsatt fortegn på disse diskursive temaene, bortsett fra at de svært religiøse også distanserer seg fra ulike grupper somaliere som lever segregert med andre somaliere, men som ikke har en religiøst forpliktende livsstil (for eksempel de som tygger mye khat).

Noen av kategoriene kan velges aktivt, mens andre kategorier kan den enkelte ikke velge å unnslippe, eller en hindres av utstøtingsmekanismer i det norske samfunnet, som når en lege jeg intervjuet forsøker å få den jobben han er utdannet til å ha, uten å klare det, og når Jimale forsøker å beholde praksisplassen og få seg utdanning, men igjen og igjen opplever at han ikke klarer det. Noen, som disse to, identifiserer seg med å ha stabile jobber og takle livet, selv om de har store problemer med å nå disse målene. For noen vil mange slike opplevelser føre til en reidentifisering, for eksempel i retning av mer ensidig somaliske miljøer, mer vekt på tradisjon, religion, eventuelt å unnslippe frustrasjonene ved å søke seg rusopplevelser, som blant mennene som samles for å tygge khat. Andre reagerer på slike erfaringer ved å finne alternative måter å nå målene på, som for eksempel å dra ut av landet, fordi de tror det vil være lettere å få jobb i England. Med andre ord vil noen innta en fornyet interesse i røtter som ved å søke seg til rent somaliske fellesskap og somaliske eller muslimske tradisjoner, og tilsvarende avvise det norske samfunnets tradisjoner, fellesskap og verdier, andre finner nye veier, som ved å flytte til et annet land, der alt er enklere, eller prøve en annen utdanning.

Skillet mellom roots og routes (eller som i Hylland Eriksens (2004) oversettelse; røtter og føtter), har etter hvert blitt et mye omtalt skille i nyere identitetsteori. Med røtter siktes til den mer essensialistiske vektleggingen av arv, slekt, kulturell bakgrunn osv., mens med føtter blir fokuset et mer konstruktivistisk syn på at man kan velge sin identitet, gå nye veier, finne frem til nye kombinasjoner fra ulike kulturelle elementer, bygge opp sin egen variant av hva det for eksempel vil si å være somalier. Som Misra sier det, det handler om å ta med seg det beste fra begge kulturer. Men det er lett å tenke at et slikt valg av den beste kombinasjonen av kulturelle tilhørigheter, eller verdier og livsstil er noe en selv fritt kan velge "på øverste hylle». Jimale er ett eksempel på at ikke alle kan velge like fritt. Ikke bare er det hudfarge, slik Salaado opplever, som hindrer et fritt valg; diskriminering, språkvansker eller andre strukturelle 
barrierer hindrer også at alle fritt kan velge de jobber man vil, eller å ta den utdannelsen man ønsker. Religion, tradisjon (roots), homogene etniske fellesskap og rus kan være trygghetsskapende faktorer hvis de andre veiene (routes) oppleves som vanskelig tilgjengelige.

Samhandlingen mellom somaliere i Norge foregår innenfor en norsk kontekst som dels kan være preget av diskriminering, det å være minoritet, det å leve i diaspora (med slektninger i mange land som man har forpliktelser overfor) osv. Følgen av denne konteksten kan være en oppsplitting av det somaliske fellesskapet. For noen somaliere vil oppbrytingen av nettverk og et ensidig bilde av somaliere i media ikke medføre noen store problemer. De har sitt eget nettverk av andre ressurssterke individer, både norske og somaliske. For andre vil oppsplittingen av tradisjonelle nettverk, eller de fortsatte konfliktene de ulike klansbaserte nettverkene imellom, kunne føre til ensomhet og frustrasjon. Flere nye former for identitet kan vokse ut av denne situasjonen. Både politiserte, kreoliserte, transnasjonale eller fornyede nasjonale identiteter i form av symbolsk etnisitet kan bli de resulterende identiteter som dannes av frustrasjon med den nye situasjonen.

\section{Noter}

1 Takk til Thomas Johansson, Gøteborg Universitet; Annick Prieur, Aalborg Universitet, Mette Andersson, Bergen Universitet; Karin Harsløf Hjelde, NAKMI; og Anila Nauni, Victoria Einagel, Espen Gran og andre kolleger ved Universitet i Oslo, samt noen av mine somaliske informanter, som jeg av anonymitetshensyn ikke kan navngi, for nyttige kommentarer til en tidlig versjon av denne artikkelen, samt to anonyme konsulenter for kommentarer til en senere versjon.

2 Etnisk identitet kan defineres som ens følelse av tilhørighet med en etnisk gruppe og de tankegangene, oppfattelsene, følelsene og atferden man har som skyldes ens etniske gruppemedlemskap (jf. Rotheram \& Phinney 1987).

$355 \%$ av somalierne i Norge har kommet i løpet av de fem siste årene (jf. SSB 2005). I januar 2005 var antallet somaliere i Norge 16.765, hvis vi inkluderer de som er født i Norge av to somaliske foreldre. Selv om flertallet av somalierne i Norge har ankommet de senere år, utgjør somaliere den sjette største innvandrergruppen fra ikke-vestlige land i Norge (SSB
2005). Kun et mindre antall somaliere hadde kommet til Norge før 1987.

4 Med enkelte unntak, har skole- og utdanningssystemet vært ute av funksjon siden borgerkrigen startet.

$527 \%$ førstegenerasjons somaliere hadde arbeid i 2004, opp mot $44 \%$ pakistanere og $69,3 \%$ av personer uten innvandrerbakgrunn (SSB 2005). Den totale inntekten for somaliske husholdninger i Norge er svært lav sammenlignet med andre innvandrergrupper.

6 Stigmatisering på grunn av hudfarge forekommer også fra somaliere sin side. En av mine somaliske informanter er indignert over at mange somaliere vurderer folk fra andre afrikanske land som underlegne somaliere fordi de er mørkere i huden. Mange somaliere mener de kan se om en annen person er fra Somalia eller ikke. De er opptatt av at de ser annerledes ut enn folk fra andre afrikanske land. På den annen side har somaliere til felles med innvandrere fra andre nasjonaliteter at de har synlig minoritetsbakgrunn. Somaliere som har levd 
hele livet i Somalias naboland, som Etiopia, Kenya og Djibouti opplever å bli mobbet eller ekskludert fordi de ikke er ekte somaliere.

7 Blant de somalierne som kom i 1991, hadde $22 \%$ emigrert innen 1999 (jf. Lie 2004).

8 Rastafarianere regner Haile Selassie som en svart Messias som vil lede Afrikas folk og den afrikanske diasporaen til frihet. Mange rastafarianere tror at Haile Selassie fortsatt lever, og at hans hyppig omtalte død var en del av en konspirasjon for å diskreditere religionen Rastafarianismen er en religion som utviklet seg på 1930-tallet i Jamaica under innflytelse av Marcus Mosiah Garvey's «Tilbake til Afrika» bevegelse (jf. Wikipedia 2004).

\section{Referanser}

Andersson, M. (2000) All Five Fingers are Not the Same. Identity Work among Ethnic Minority Youth in an Urban Norwegian Context. Doktoravhandling, Universitet i Bergen.

Barth, F. (red.) (1969) Ethnic groups and Boundaries. The Social Organization of Cultural Difference. Oslo: Universitetsforlaget.

Bradley, H. (1996) Fractured Identities: Changing Patterns of Inequality. Cambridge: Polity Press.

Du Bois, W. E. B. (1903/1994) The Soul of Black Folk. New York: Harper.

Eidheim, H. (1987) 'Assimilation, Ethnic Incorporation and the Problem of Identity Management', i H. Eidheim Aspects of the Lappish Minority Situation, s 68-82. Occasional Papers in Social Anthropology, no. 14. Oslo: University of Oslo.

Engebrigtsen, A. (2004) 'Somaliere $i$ eksil $i$ Norge. En kartlegging av erfaringer fra fem kommuner og åtte bydeler $i$ Oslo. NOVA skriftserie, nr. 1. Oslo: NOVA.

Eriksen, T. H. (1995) 'We and Us: Two Modes of Group Identification', Journal of Peace Research 32: 427-36.

Eriksen, T. H. (2003) Hva er antropologi? Oslo: Universitetsforlaget.

Eriksen, T. H. (2004) Røtter og føtter. Oslo: Universitetsforlaget.

Gans, H. J. (1996) 'Symbolic Ethnicity', i J. Hutchinson og A. Smith (red.) Ethnicity. Oxford: Oxford University Press.

Gardner, K. og Shukur, A. (1994) ' «I'm Bengali, I'm Asian, and I'm Living Here.»' The Changing Identities of British Bengalis', i R. Ballard (red.) Desh Pardesh: The South Asian Presence in Britain. London: Hurst.

Goffman, E. (1969) 'The Interaction Order'. American Sociological Review 48:1-17.
Gullestad, M. (2003) 'Fighting for a Sustainable SelfImage. The Role of Descent in Individualized Identification', Focaal - European Journal of Anthropology 42: 51-62.

Gundel, J. (2002) 'The Migration-Development Nexus: Somalia Case Study', International Migration 40: 255-281.

Hall, S. (1996) 'Introduction: Who Needs "Identity"?', i S. Hall og P. du Gay (red.) Questions of Cultural Identity. London: Sage.

Hannerz, U. (1992) Cultural Complexity: Studies in the Social Organization of Meaning. New York: Columbia University Press.

Hassan, H. (2002) ' "Not Housekeepers Any More»: Somali Women of the Diaspora', URL (7.11.2002): http://www.mafhoum.com/press4/120S66.htm.

Hassan, H. (2004) 'The Phones Keep Ringing in World's Poorest Country', URL http://www.globalenvision.org/library/3/526/.

Hebdige, D. (1979) Subculture. The Meaning of Style. London: Routledge.

Jenkins, R. (1987) Rethinking Ethnicity. Arguments and Explorations. London: Sage.

Klepp, I. (2002) Ein diskursiv analyse av relasjonar mellom somaliske familiar og lokalbefolkninga $i$ ein vestnorsk bygdeby. Hovedoppgave i sosialantropologi, Universitetet i Bergen

Lewis, I. M. (2002) A Modern History of the Somali Nation and State in the Horn of Africa. Revised, Updated $\theta$ Expanded. Oxford: James Currey.

Lie, B. (2004) Fakta om ti innvandrergrupper. Oslo: SSB. McMichael, C. (2002) 'Islam and Somali Women in Melbourne', Journal of Refugee Studies 15: 171-188. Phoenix, A. (2002) '(Re)constructing Gendered and 
Ethnicised Identities: Are We All Marginal Now?', i T. Johansson og O. Sernhede (red.) Lifestyle, Desire And Politics: Contemporary Identities, s. 129-154. Kungälv: Daidalos.

Prieur, A. (2002) 'Fargens betydning. Om rasisme og konstruksjon av etniske identiteter', Sosiologi $i$ dag, 4:59-82.

Prieur, A. (2004) Balansekunstnere. Betydningen av innvandrerbakgrunn i Norge. Oslo: Universitetsforlaget.

Portes, A. og Rumbaut, R. G. (2001) Legacies. Story of the Immigrant Second Generation. Berkeley: University of Calfornia Press.

Rotheram, M. J. og Phinney, J. S. (red.) (1987) Children's Ethnic Socialization: Pluralism and Development. Newbury Park: Sage.

Sernhede, O. (2002) AlieNation is my Nation. Hip hop och unga mäns utanförskap $i$ Det Nya Sverige. Stockholm: Ordfront förlag.
Skeggs, B. (1997) Formations of Class and Gender. Becoming Respectable. London: Sage.

SSB (2005) Sysselsatte førstegenerasjonsinnvandrere, (http://www.ssb.no/emner/06/01/innvregsys/tab2005-06-23-09.html).

SSB (2005) Befolkningsstatistikk. Innvandrerbefolkningen, 1. januar 2005, (http://Www.ssb.no/ emner/02/01/10/innvbef//).

Talle, A. (2003) Om kvinneleg omskjering - Debatt og erfaring. Oslo: Samlaget.

Werbner, P. (2001) 'The limits of cultural hybridity: on ritual monsters, poetic licence and contested postcolonial purifications', Journal of Royal Anthropological Institute 7:133-152.

Østberg, S. (2003) Pakistani Children in Norway: Islamic Nurture in a Norwegian Context. Leeds: Department of Theology and Religious Studies, University of Leeds. 